\title{
Article \\ Identification and Characterization of Short Crown Root 8, a Temperature-Sensitive Mutant Associated with Crown Root Development in Rice
}

\author{
Peng $\mathrm{Hu}{ }^{1,2,+}$, Yi Wen ${ }^{1,3,+}$, Yueying Wang ${ }^{1}$, Hao Wu ${ }^{1}$, Junge Wang ${ }^{1}$, Kaixiong Wu ${ }^{1}$, Bingze Chai ${ }^{1}$, Lixin Zhu ${ }^{1}$, \\ Guangheng Zhang ${ }^{1}{ }^{\mathbb{D}}$, Zhenyu Gao ${ }^{1}$, Deyong Ren ${ }^{1}$, Li Zhu ${ }^{1}$, Longbiao Guo ${ }^{1}{ }^{\mathbb{D}}$, Dali Zeng ${ }^{1}$, Jing Xu ${ }^{1}$, \\ Song Yan ${ }^{4}$, Qian Qian ${ }^{1,2}$, Yuchun Rao ${ }^{5, *}$ and Jiang $\mathrm{Hu}^{1, *}$ \\ check for \\ updates \\ Citation: Hu, P.; Wen, Y.; Wang, Y.; \\ Wu, H.; Wang, J.; Wu, K.; Chai, B.; \\ 1 State Key Laboratory of Rice Biology, China National Rice Research Institute, Hangzhou 310006, China; \\ 15168331324@126.com (P.H.); Wenyi199492@hotmail.com (Y.W.); wyywangyueying@163.com (Y.W.); \\ wuhaoge1987@163.com (H.W.); 15038793321@163.com (J.W.); 15932930488@163.com (K.W.); \\ 13204660061@163.com (B.C.); zhulixin96@foxmail.com (L.Z.); zhangguangheng@126.com (G.Z.); \\ zygao2000@hotmail.com (Z.G.); rendeyongsd@163.com (D.R.); zhuli05@caas.cn (L.Z.); \\ guolongbiao@caas.cn (L.G.); dalizeng@126.com (D.Z.); xujing87@126.com (J.X.); \\ qianqian188@hotmail.com (Q.Q.) \\ 2 Agricultural Genomics Institute at Shenzhen, Chinese Academy of Agricultural Sciences, \\ Shenzhen 518120, China \\ 3 Rice Research Institute of Shenyang Agricultural University/Key Laboratory of Northeast Rice Biology \\ and Breeding, Ministry of Agriculture, Shenyang 110866, China \\ 4 Rice Research Institute, Jiangxi Academy of Agricultural Sciences, Nanchang 330200, China; yans11@163.com \\ 5 College of Chemistry and Life Sciences, Zhejiang Normal University, Jinhua 321004, China \\ * Correspondence: ryc1984@163.com (Y.R.); hujiang588@163.com (J.H.); Tel.: +86-0579-82282269 (Y.R.); \\ +86-571-63370179 (J.H.) \\ + These authors contributed equally to this work.
} Zhu, L.; Zhang, G.; Gao, Z.; et al. Identification and Characterization of Short Crown Root 8, a TemperatureSensitive Mutant Associated with Crown Root Development in Rice. Int. J. Mol. Sci. 2021, 22, 9868. https:// doi.org/10.3390/ijms22189868

Academic Editors: Prasanta K. Subudhi and Setsuko Komatsu

Received: 31 July 2021

Accepted: 8 September 2021

Published: 13 September 2021

Publisher's Note: MDPI stays neutral with regard to jurisdictional claims in published maps and institutional affiliations.

Copyright: (c) 2021 by the authors. Licensee MDPI, Basel, Switzerland. This article is an open access article distributed under the terms and conditions of the Creative Commons Attribution (CC BY) license (https:// creativecommons.org/licenses/by/ $4.0 /)$

\begin{abstract}
Crown roots are essential for plants to obtain water and nutrients, perceive environmental changes, and synthesize plant hormones. In this study, we identified and characterized short crown root 8 (scr 8$)$, which exhibited a defective phenotype of crown root and vegetative development. Temperature treatment showed that $s c r 8$ was sensitive to temperature and that the mutant phenotypes were rescued when grown under low temperature condition $\left(20^{\circ} \mathrm{C}\right)$. Histological and EdU staining analysis showed that the crown root formation was hampered and that the root meristem activity was decreased in scr8. With map-based cloning strategy, the SCR8 gene was fine-mapped to an interval of $126.4 \mathrm{~kb}$ on chromosome 8 . Sequencing analysis revealed that the sequence variations were only found in LOC_Os08g14850, which encodes a CC-NBS-LRR protein. Expression and inoculation test analysis showed that the expression level of LOC_Os08g14850 was significantly decreased under low temperature $\left(20^{\circ} \mathrm{C}\right)$ and that the resistance to Xanthomonas oryzae pv. Oryzae (Xoo) was enhanced in scr8. These results indicated that LOC_Os08g14850 may be the candidate of SCR 8 and that its mutation activated the plant defense response, resulting in a crown root growth defect.
\end{abstract}

Keywords: crown root; defense response; temperature-sensitive; scr8; rice

\section{Introduction}

Plant roots determine the absorption of water and nutrients and fix and support the aboveground parts, which directly affect plant growth and development [1]. Plant root systems are divided into two main types: fibrous root systems and taproot systems. Dicotyledons possess taproot systems, which include the main root and lateral roots, while monocotyledons have fibrous root systems, including primary roots, crown roots (also called adventitious roots), and lateral roots. Rice is a monocotyledonous plant, and its crown roots mainly undergo three stages of development: initiation, emergence, and 
elongation, in which the abnormal development will directly affect the morphology of roots $[2,3]$.

Root growth and development are derived from stem cells, which divide into root apical meristem (RAM) to enter the elongation/differentiation zone to initiate cell differentiation [4]. To ensure root meristem maintenance, the cell division and differentiation must be coordinated, and disturbance of the balance will affect the RAM activity, resulting in abnormal development of root length and size [4-6]. Several regulatory pathways have been reported to affect crown root development, in which the generation and differentiation of RAM plays an important role. WOX11 encodes a WUSCHEL (WUS)-related homeobox protein that regulates crown root meristem cell proliferation by recruiting the ADA2-GCN5 histone acetyltransferase module to activate downstream target genes [7]. ROOT MERISTEM GROWTH FACTOR 1 (RGF1) is a critical peptide hormone, and RGF1RGI1 determines primary root growth and development by regulating the expression of PLT1/PLT2 via the YDA-MKK4/MKK5-MPK3/MPK6 signaling cascade [8,9]. The microRNAs (miRNAs) are endogenous small non-coding RNAs that mediate crown root development. LOWER CROWN ROOT NUMBER 1 (LCRN1) encodes SQUAMOSA PROMOTER BINDING PROTEIN-LIKE 3(SPL3), which regulates crown root development through the OsmiR156-OsSPL3/OsSPL12 pathway [10]. Xpo1 domain protein of CROWN ROOT DEFECT 1 (CRD1) is essential for maintaining normal miRNA levels, and its mutation leads to the disruption of the miR156 regulatory pathway and significant inhibition of crown root development [11]. In addition, temperature is also an important external environmental factor affecting crown root development. BRASSINOSTEROID INSENSITIVE 1 (BRI1) mediates root elongation by downregulating brassinosteroid signaling at high temperatures [12]. Loss-of-function of ADAPTATION TO ENVIRONMENTAL TEMPERATURE 1 (AET1) results in a short crown root and insensitivity to auxin in high temperatures [13]. Moreover, the root growth defects caused by hybrid weakness can also be recovered by low-temperature treatment [14].

Several factors affecting the balance between cell division and cell differentiation are involved in regulating root meristem activity. The complex network of interactions of hormonal pathways plays a key role in root meristem activity regulation. Plant endogenous hormones, such as auxin, cytokinin (CK), gibberellin (GA), salicylic acid (SA), and jasmine acid (JA), are critical factors involved in root development [15]. Among them, auxin promotes root growth and development, and plant treatment with auxin induces lateral root and adventitious root formation [16,17]. In Arabidopsis thaliana, MUSTACHES (MUS) and MUSTACHES-LIKE (MUL) were regulated by AUXIN RESPONSE FACTOR7 (ARF7) and $A R F 19$, and the mutations of MUS and MUL inhibited lateral root growth [18,19]. Moreover, the $P R-1$ HOMOLOG gene $(P R H)$ was found to regulate lateral root formation through the ARF7/LBD pathway [20,21]. In rice, CROWN ROOTLESS 1 (CRL1)/ ADVENTITIOUS ROOTLESS 1 (ARL1) encodes a LOB-domain transcription factor and regulates crown root formation by positively regulating the expression of meristem- and cell proliferationrelated gene [22-24]. In contrast with auxin, cytokinin plays an inhibitory effect on root growth. WOX11 interacts with AP2/ETHYLENE-RESPONSIVE FACTOR (ERF3) to regulate the expression of CYTOKININ TYPE-A RESPONSIVE REGULATOR (RR2) during crown root formation and development [2,25]. ROOT ENHANCER 1 (REN1)/CYTOKININ OXIDASE/DEHYDROGENASE 4 (CKX4) affects crown root formation by integrating the cytokinin and auxin pathways [26]. Recent studies have found that the E3 ubiquitin ligase complex APC/CTE is activated by high gibberellins levels and inhibits root meristem growth by mediating SHORTROOT 1 (OsSHR1) degradation [27]. In addition, SA and JA regulate crown root growth. The short root phenotype of ABNORMAL INFLORESCENCE MERISTEM1 (AIM1) mutant is rescued by SA treatment in rice [6], and JA participates in inducing the activation and regeneration of root stem cells by regulating the RBR-SCR network and the stress response protein ERF115 in Arabidopsis thaliana [28].

To date, few genes have been reported to be involved in crown root development. Therefore, the identification of new crown root mutants can help further cloning of related 
genes and enriching its molecular regulatory network. In this study, we identified a novel short crown root mutant that displayed reduced root growth phenotype. The $s c r 8$ is temperature sensitive and exhibits short crown root at high temperature $\left(32{ }^{\circ} \mathrm{C}\right)$ and presents normal crown root at low temperature $\left(20^{\circ} \mathrm{C}\right)$. Map-based cloning revealed that LOC_Os08g14850 may be the candidate gene that encodes a CC-NB-LRR-type protein involved in the plant defense response. We demonstrated that the mutation of SCR8 disturbed the balance between plant growth and defense response, resulting in the crown root growth inhibition.

\section{Results}

\subsection{Identification of Scr8 Mutant}

The scr 8 mutant was obtained from a natural variation of indica variety R1206. Phenotypic observation showed that the mutant exhibited reduced growth, including shortened plant height, panicle length, and reduced tiller number (Figure 1A,D-F). Further phenotypic measurements showed that grain length, 1000-grain weight, and spikelet number of panicles were also significantly reduced, but there was no change in grain width compared with wildtype (WT) (Figure 1B,C,H-J). In addition, the root development of scr 8 was significantly inhibited and the plants easily perished in the field (Figure 2A-D). These results show that the growth and development of $s c r 8$ was seriously impaired, which eventually led to a reduction in biomass.
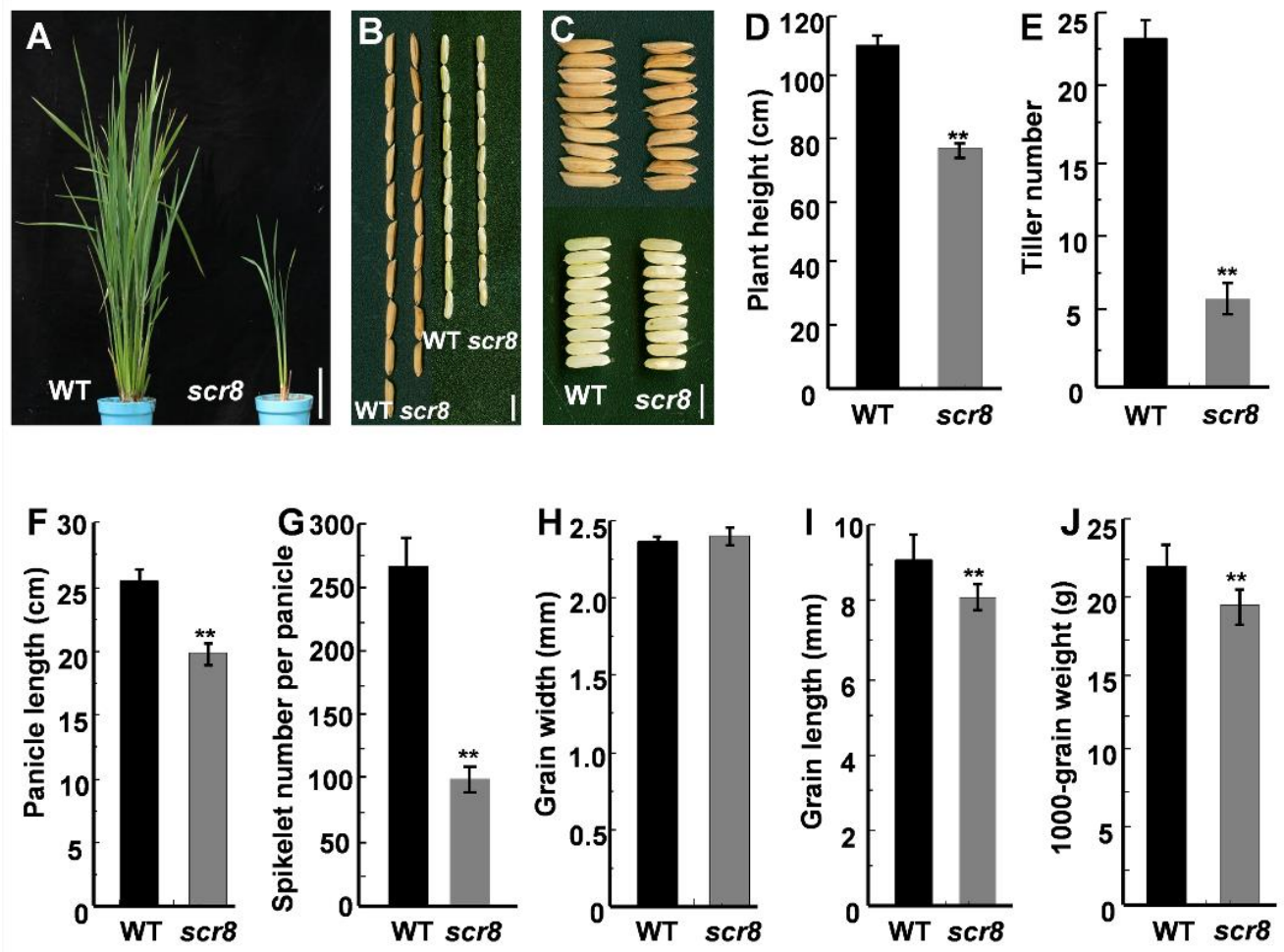

Figure 1. Characterization of WT and scr 8 mutant. (A) Plant architecture of WT and scr 8 mutant plants at the booting stage. Scale bars, $10 \mathrm{~cm}$. (B,C) Mature paddy rice grains and brown rice grains from WT and scr 8 . Scale bars, $0.5 \mathrm{~cm}$. (D-J) Comparisons between WT and scr 8 for average plant height ( $\mathrm{n}=15$ plants) $(\mathrm{D})$, average tiller number $(\mathrm{n}=15$ plants) $(\mathrm{E})$, average panicle length ( $\mathrm{n}=15$ plants) $(\mathbf{F})$, average spikelet number per panicle $(\mathrm{n}=15$ plants) $(\mathrm{G})$, average grain width $(\mathrm{n}=15$ plants) $(\mathbf{H})$, average grain length $(\mathrm{n}=15$ plants) $(\mathrm{I}), 1000$-grain weight $(\mathrm{n}=15$ plants $)(\mathrm{J})$. Error bars represent standard deviation (SD). ${ }^{*}$ Significant difference at $p<0.01$ compared with the WT by Student's $t$-test. 

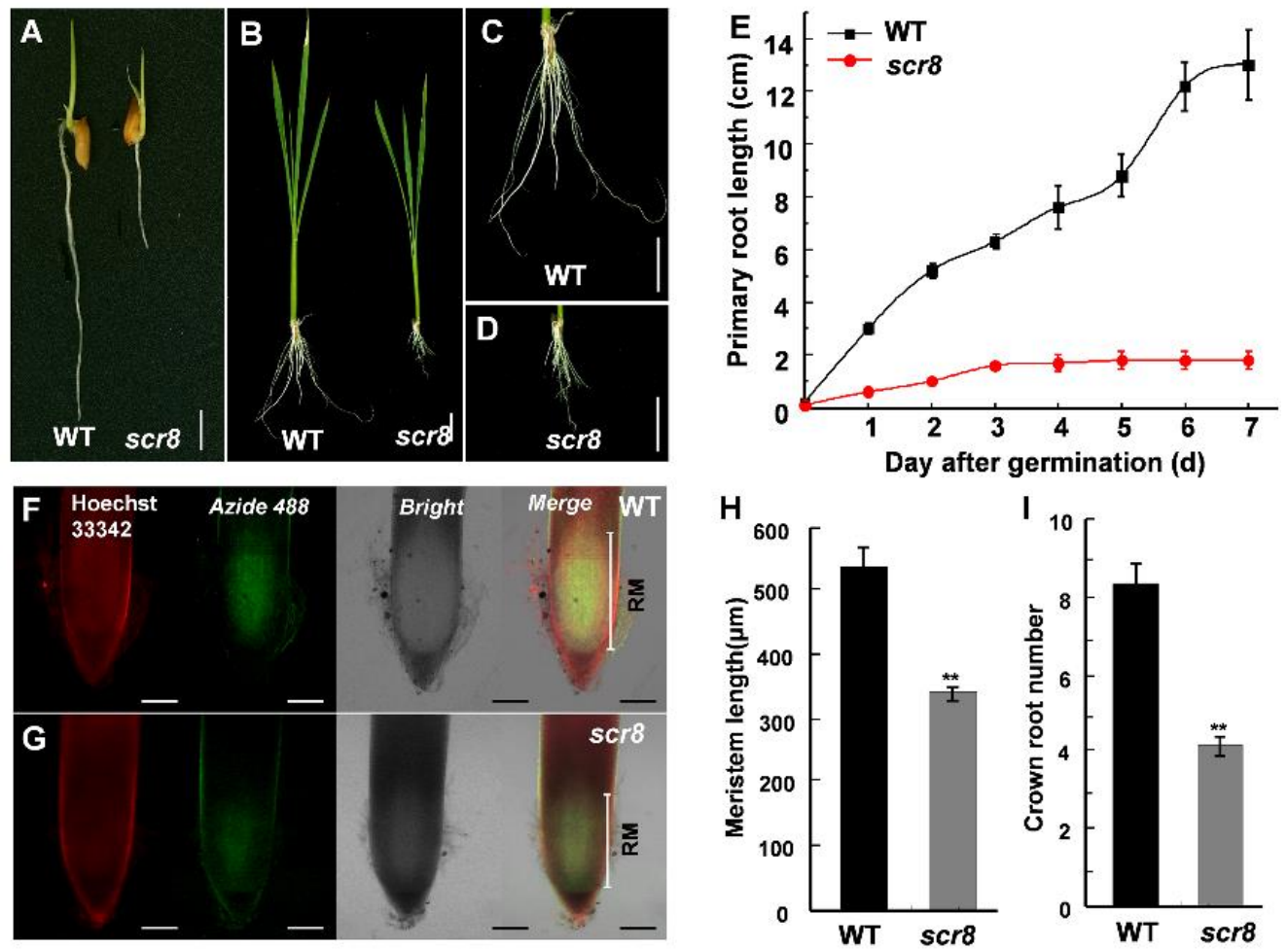

Figure 2. The meristem activity of WT and scr8. (A) Root phenotype of 3-day-old WT and scr8. Scale bars, $1 \mathrm{~cm}$. (B-D) Root phenotype of 30-day-old WT and scr8. Scale bars, $1 \mathrm{~cm}$. (E) Primary root length of WT and scr8 after germination $(\mathrm{n}=10)$. $(\mathbf{F})$ and $(\mathrm{G})$ EdU staining analysis of 3-day-old WT and scr8. Scale bars, $100 \mu \mathrm{m}$. (H) Meristem length of 3-day-old WT and scr8 (n=3). (I) Crown root number of 7-day-old WT and scr8 $(\mathrm{n}=10)$. Error bars represent SD. ${ }^{* *}$ Significant difference at $p<0.01$ compared with the WT by Student's $t$-test.

\subsection{Reduced Root Meristem Activity of Scr8}

After germination, scr8 initially showed a phenotype of impaired shoot and root growth, especially crown root (Figure 2A-E). Moreover, the elongation of crown root ceased on third day, and the root number was also significantly reduced in scr 8 compared with the WT (Figure 2E,I). To detect the differences in root meristem activity, EdU (5ethynyl-29-deoxyuridine), a thymidine analog, was used to detect cell proliferation. The results show that the amount of EdU labeling was significantly reduced in the mutant compared with the WT (Figure 2F-H), indicating root meristem activity was decreased in scr8.

\subsection{Anatomic Analysis of Scr8}

To further understand the scr 8 phenotype, the histological characteristics of the culms and basal nodes were observed by paraffin section. Due to crown root growth initiation in the tissue of root basal node, we carried out the microscopic observation. The result indicates that crown root formation was severely hampered and that the number of crown root primordia were significantly reduced (Figure $3 \mathrm{~A}, \mathrm{~B}$ ), which suggests that the defected crown root growth of $s c r 8$ was mainly due to decreased meristem activity and fewer root primordia. Compared with the wildtype, the vascular numbers and cell length of culms were significantly reduced, which is consistent with the inhibited growth phenotype of $s c r 8$ (Figure 3C-H). 

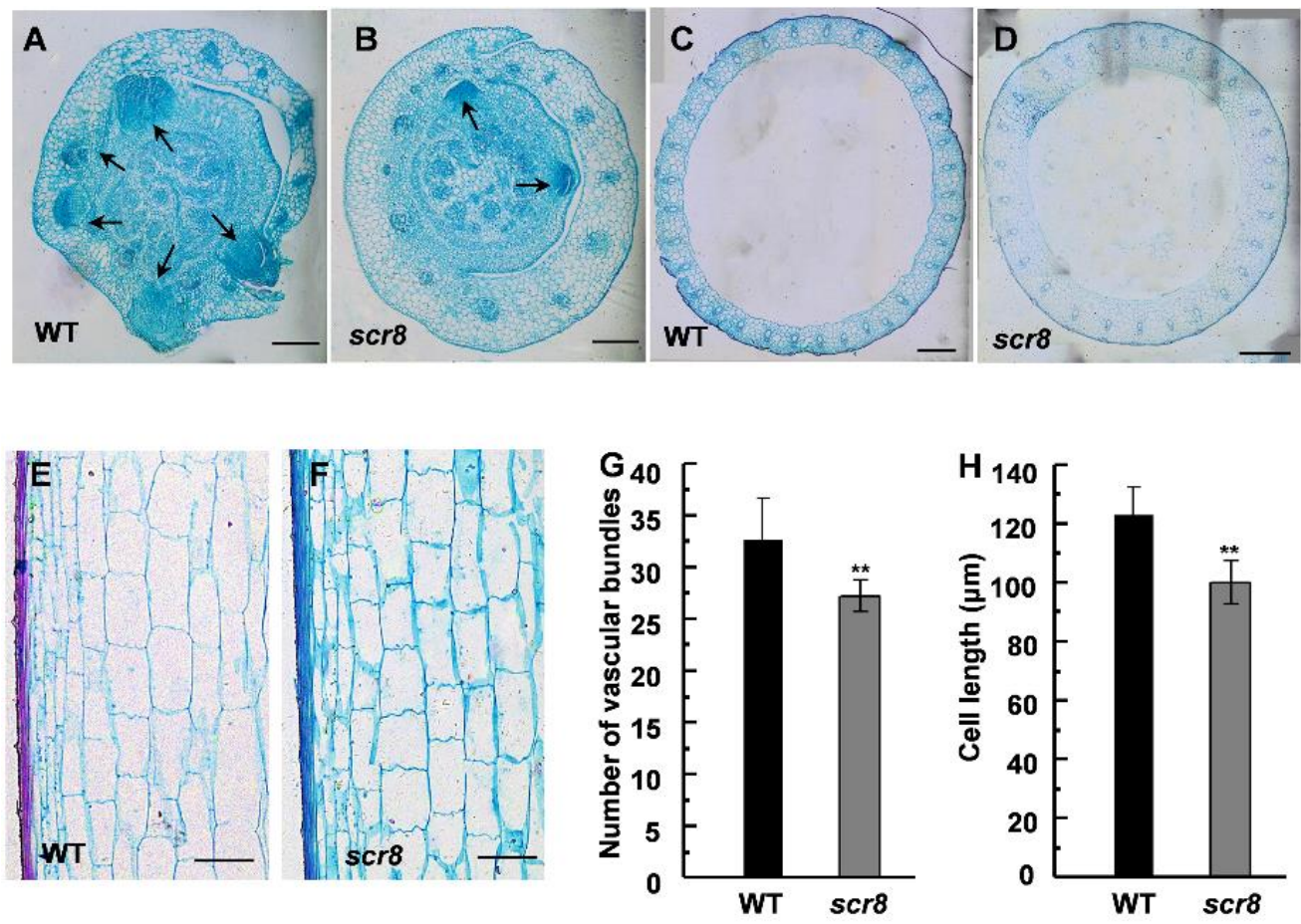

Figure 3. Histological characterization of basal nodes and culms. (A,B) Cross sections of basal nodes from WT and scr8 mutant plants. Arrow represents crown root primordia. Scale bars, $200 \mu \mathrm{m}$. (C,D) Cross sections of culms from WT and scr 8 mutant plants. Scale bars, $200 \mu \mathrm{m}$. (E,F) Longitudinal sections of culms from WT and scr 8 mutant plants. Scale bars, $100 \mu \mathrm{m}$. (G) Average number of vascular bundles of culms in WT and scr8. (H) Average cell length of culms in WT and scr8. Error bars represent SD. ${ }^{* *}$ Significant difference at $p<0.01$ compared with the WT by Student's $t$-test.

\subsection{Temperature Affected Scr8 Root Growth}

Temperature is a major abiotic stress in plant growth and development, including germination, growth, flowering, and disease resistance [13,14]. In this study, scr 8 was sensitive to high temperatures and displayed severe root growth defects above $28^{\circ} \mathrm{C}$ (Figure $4 \mathrm{~A}, \mathrm{~B}, \mathrm{E}, \mathrm{F}$ ). However, at temperatures below $24^{\circ} \mathrm{C}$, the root development of $s c r 8$ was normal, and the root lengths were the same as those of the wildtype (Figure $4 \mathrm{C}, \mathrm{D}, \mathrm{G}, \mathrm{H}$ ). In addition, the $s c r 8$ growth defects were reversed by low-temperature treatment. We shifted the temperature from $32{ }^{\circ} \mathrm{C}$ to $20^{\circ} \mathrm{C}$, and root growth of $s c r 8$ increased significantly. Conversely, scr 8 growth was inhibited when the temperature was increased from $20{ }^{\circ} \mathrm{C}$ to $32{ }^{\circ} \mathrm{C}$ (Figure $\left.4 \mathrm{I}-\mathrm{K}\right)$.

\subsection{Scr8 Showed Increased SA and JA Content}

Hormones play an important role in regulating plant growth and development, and previous studies have shown that the metabolism of SA and JA is a key factor in regulating plant root growth $[6,29]$. To clarify whether the scr 8 root phenotype is related to SA or JA, we measured the free SA and JA concentrations at the seedling stage and found higher accumulations of SA and JA in scr8 compared with the wildtype (Figure 5B,C). Among them, the SA content in both scr8 shoots and roots was significantly higher than WT, but the content of JA was only higher in roots. In fact, the mutant phenotype is more apparent in roots than shoots, which is consistent with the variation in JA content (Figure 5A-C). Therefore, we speculated that JA may be the main hormone affecting the development of $s c r 8$. 

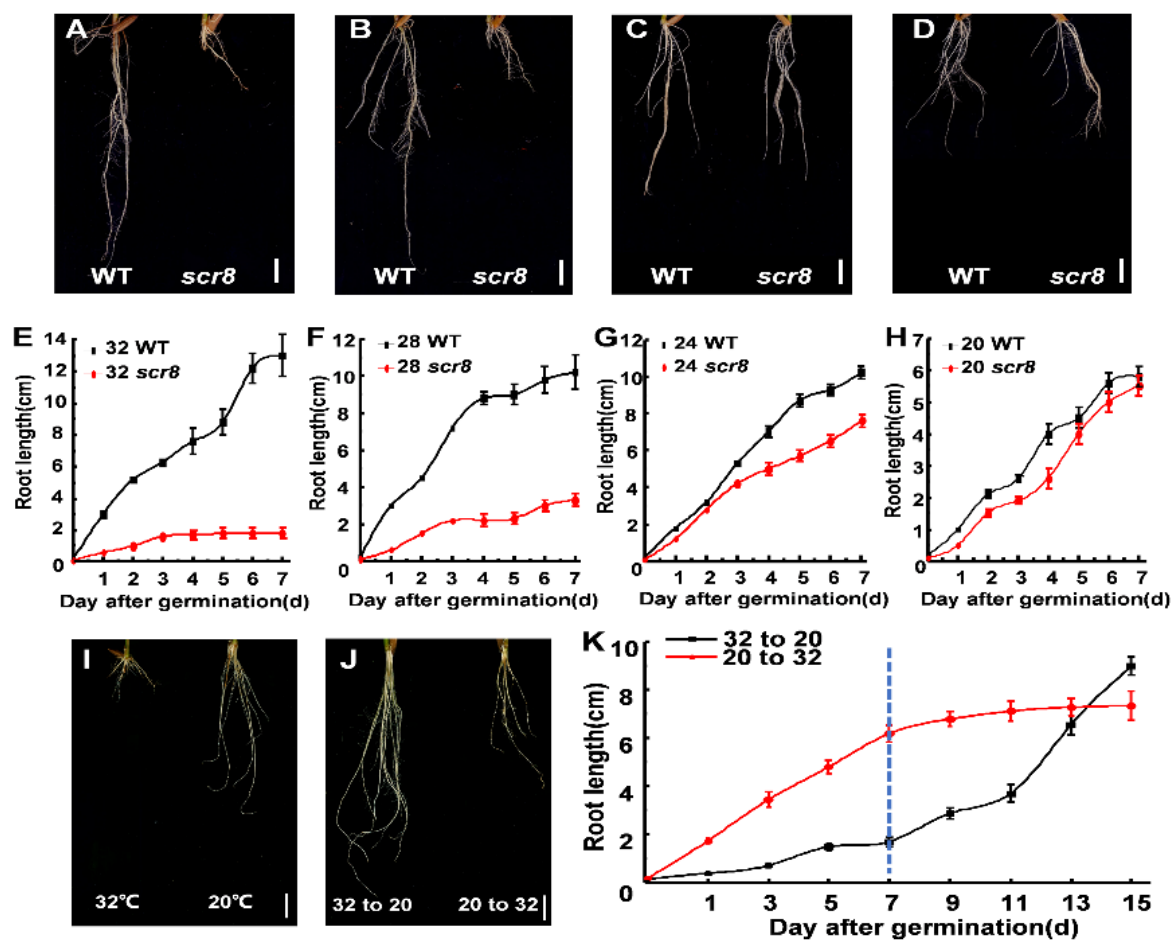

Figure 4. Different temperature treatment and temperature shift experiment. (A-D) Morphology of WT and scr 8 under various temperature conditions: $32{ }^{\circ} \mathrm{C}$ treatment $(\mathbf{A}), 28^{\circ} \mathrm{C}$ treatment $(\mathbf{B}), 24{ }^{\circ} \mathrm{C}$ treatment $(\mathbf{C}), 20^{\circ} \mathrm{C}$ treatment (D). Scale bars, $1 \mathrm{~cm}$. (E-H) Time-course measurements of root length in WT and scr 8 mutant plants: $32{ }^{\circ} \mathrm{C}$ treatment (E), $28^{\circ} \mathrm{C}$ treatment (F), $24{ }^{\circ} \mathrm{C}$ treatment (G), $20^{\circ} \mathrm{C}$ treatment $(\mathbf{H})$. $(\mathbf{I}, \mathbf{J})$ temperature shift experiment of scr 8 . Root phenotype of scr 8 grown at $32{ }^{\circ} \mathrm{C}$ and $20^{\circ} \mathrm{C}(\mathbf{I})$, Root phenotype of scr 8 after temperature shift (J). Scale bars, $1 \mathrm{~cm}$. "32 to 20" and "20 to 32" indicate that the temperature was changed from $32{ }^{\circ} \mathrm{C}$ to $20{ }^{\circ} \mathrm{C}$ or from $20{ }^{\circ} \mathrm{C}$ to $32{ }^{\circ} \mathrm{C}$ at 7 days after germination. (K) Time course analysis of root length of in response to temperature-shift treatment.
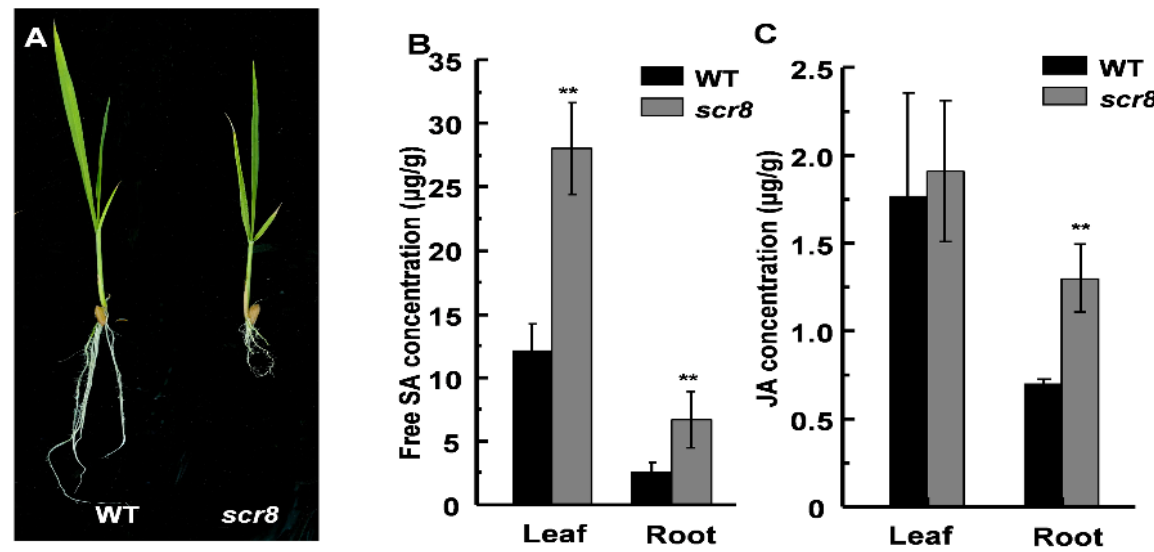

Figure 5. The contents of SA and JA in WT and scr8. (A) The phenotype of WT and scr8 in seedling. Scale bar, $1 \mathrm{~cm}$. (B) Contents of free SA in WT and scr8 leaves and roots $(n=3)$. (C) Contents of JA in WT and scr 8 leaf and roots $(n=3)$. Error bars represent SD. ${ }^{* *}$ Significant difference at $p<0.01$ compared with the WT by Student's $t$-test.

\subsection{Fine Mapping of Scr8 and Candidate Gene Analysis}

To identify the mutant gene, an $\mathrm{F}_{2}$ population was developed by crossing $s c r 8$ with japonica variety WYG7, and the segregation of wildtype and mutant phenotypes displayed a ratio of 3:1 (74 mutant-type: 255 WT-type, $\chi^{2}=0.974<\chi^{2} 0.05=3.84$ ), indicating 
that the mutant phenotype was controlled by a single recessive gene. SCR8 was first mapped to chromosome 8, between molecular markers ZW2 and ZW3, and its location was then narrowed down to a $126.4 \mathrm{~kb}$ genomic region between the markers ZW8 and ZW9 using 768 homozygous mutant plants (Figure 6A,B). In this region, a total of 22 predicted opening reading frames (ORFs) were found according to the publicly available rice database, Rice Genome Annotation Project (http:/ / rice.plantbiology.msu.edu/index.shtml accessed on 16 June 2021), in which a resistance protein gene of the NB-ARC domain, LOC_Os08g14850, was the most likely candidate (Figure 6C,D). The promoter and coding regions of the 22 genes were amplified and sequenced, and seven variations were found only in LOC_Os08g14850. We carried out qRT-PCR analysis, and the results indicate that the expression of LOC_Os08g 14850 was significantly increased in $s c r 8$ when grown at $32{ }^{\circ} \mathrm{C}$, but there was no change at $20^{\circ} \mathrm{C}$ (Figure 6E). Thus, we considered LOC_Os08g14850 to be a candidate gene for SCR8.

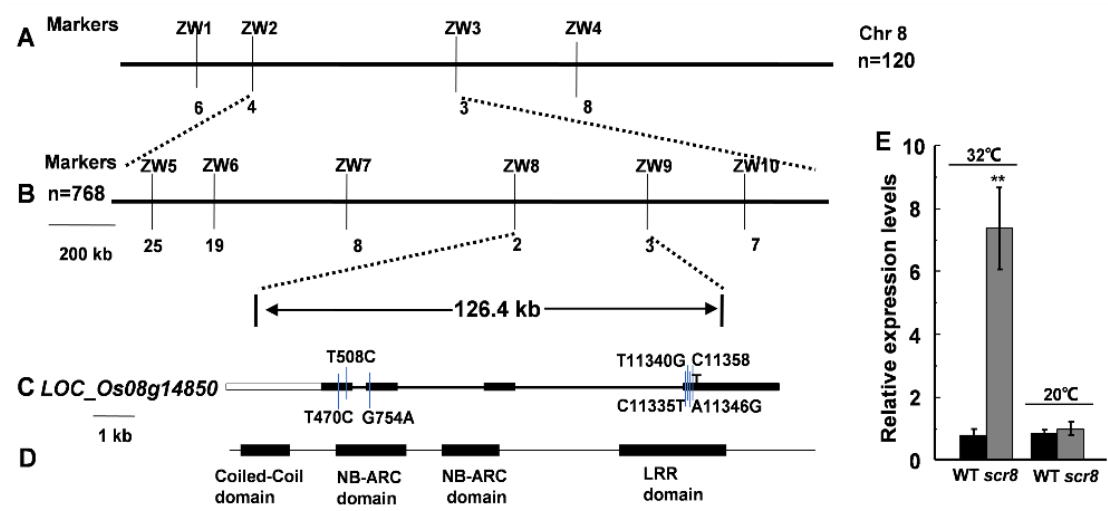

Figure 6. Fine mapping of the SCR 8 gene. (A,B) Fine mapping of the SCR 8 gene. (C,D) Structure analysis of SCR8. (E) Relative expression level of LOC_Os08g14850 grown at $32{ }^{\circ} \mathrm{C}$ and $20^{\circ} \mathrm{C}$. Error bars represent SD. ${ }^{* *}$ Significant difference at $p<0.01$ compared with the WT by Student's $t$-test.

\subsection{Transcriptome Analysis of the Wildtype and Scr8 Mutant}

To characterize the molecular regulatory network of SCR8, RNA-seq analysis was performed on plants grown at $20^{\circ} \mathrm{C}$ and $28^{\circ} \mathrm{C}$. In total, $272 \mathrm{DEGs}$ (differentially expressed genes, false discovery rate $<0.05$ and induction fold $>1$ ), including 136 upregulated genes and 136 downregulated genes between the WT and scr 8 were identified when grown at $28^{\circ} \mathrm{C}$, and 1553 DEGs (813 upregulated and 740 downregulated genes) between $20^{\circ} \mathrm{C}$ and $28^{\circ} \mathrm{C}$ were also found in scr 8 (Figure 7A,B). Gene ontology (GO) analysis classified most of the DEGs as being involved in catalytic activity, oxidoreductase activity, oxidationreduction processes, and cellular catabolic processes in scr 8 compared with the WT when grown at $28{ }^{\circ} \mathrm{C}$ (Table S2). After low-temperature treatment $\left(20^{\circ} \mathrm{C}\right)$, the significantly enriched GO terms were catalytic activity, single-organism processes, single-organism cellular processes, and oxidoreductase activity (Figure 7C,D; Table S3). Among these DEGs, a number involved in cell cycle and hormone synthesis were identified, including CycA1;1, CycD5;2, WRKY53, JAZ9, JAZ11, RR2, and RR4 (Tables S4 and S5). To evaluate the reliability of the RNA-seq data, we selected some upregulated and downregulated genes for validation by qRT-PCR, and the results were consistent (Figure 7E-I).

\subsection{Scr8 Showed Enhanced Resistance to Xoo}

Since LOC_Os08g14850 is predicted to be a resistance protein, and its expression was significantly enhanced in $s c r 8$, a bacterial blight inoculation test was carried out with Xoo strains Zhe173 and PXO99A at the heading stage. To quantify the pathogen responses, the lesion lengths were measured after 15 days, and the results show that the lesion lengths of scr 8 were significantly shorter than those of WT (Figure 8A-D). Moreover, the transcription level of pathogen-related genes (PRs) OsPR1a, OsPR1b, OsPR4, and PBZ1 were detected, and the expression levels of these genes were also significantly higher in scr8 (Figure 8E). 
A

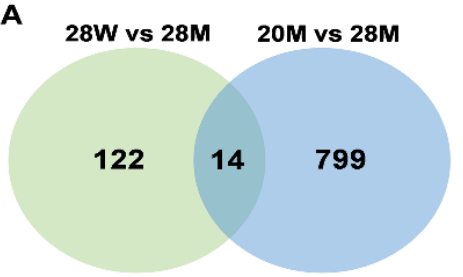

Upregulated genes

C

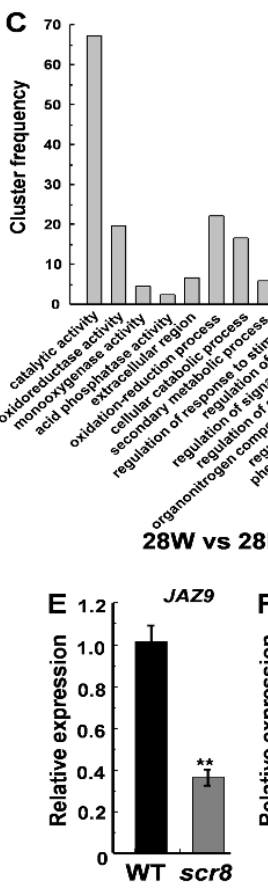

B

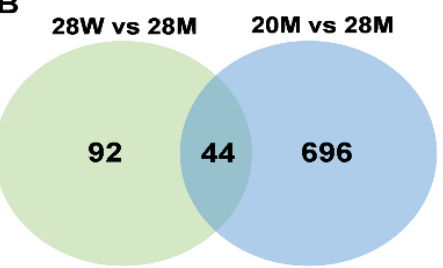

Downregulated genes

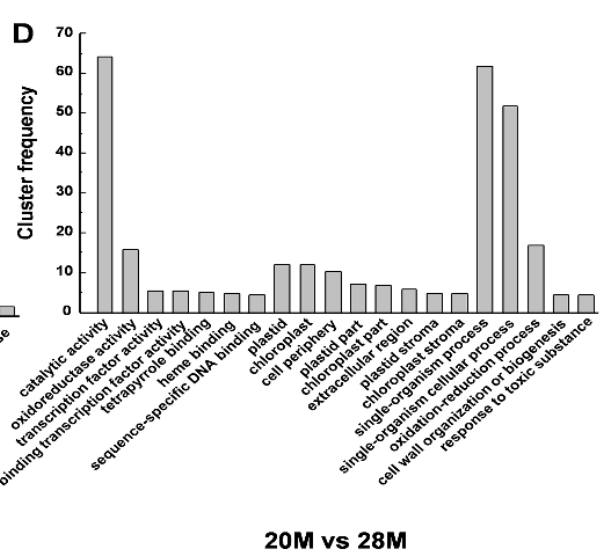

$20 M$ vs $28 M$

Figure 7. Transcriptome analysis of the WT and scr8 under different temperature treatment. $(\mathbf{A}, \mathbf{B})$ Venn diagrams showing transcriptome changes in 7-day-old WT and scr 8 grown at $20{ }^{\circ} \mathrm{C}$ and $28^{\circ} \mathrm{C}$. The number of upregulated genes in $\operatorname{scr} 8$ (A). The number of downregulated genes in scr8 (B). (C) Top 20 significantly enriched GO terms compared between WT and scr8 when grown under high temperature. (D) Top 20 significantly enriched GO terms in scr 8 after low temperature treatment. (E-I) Relative expression of JAZ9, JAZ11, RR2, RR4, and WRKY53 genes in 7-day-old WT and scr8. Error bars represent SD. ${ }^{*}$ Significant difference at $p<0.01$ compared with the WT by Student's t-test.
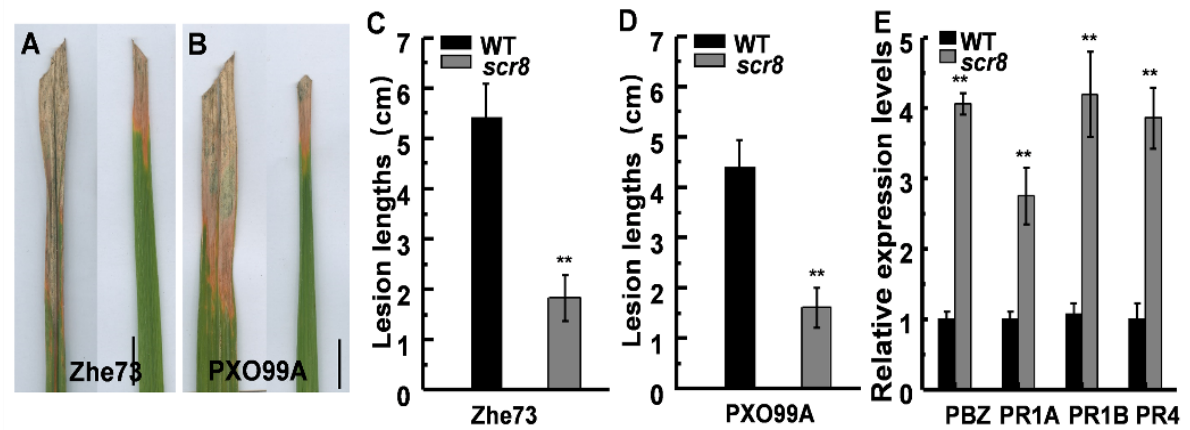

Figure 8. scr8 induced pathogenesis-related genes and disease resistance. (A) Leaf phenotype of WT and scr 8 after inoculation with Zhe173. Scale bar, $1 \mathrm{~cm}$. (B) Leaf phenotype of WT and scr 8 after inoculation with PXO99A. Scale bar, 1cm. (C) Lesion length after inoculation Zhe173. (D) Lesion length after inoculation PXO99A. (E) Relative expression levels of pathogenesis-related genes in WT and scr 8 plants at heading stage. Error bars represent SD. ${ }^{* *}$ Significant difference at $p<0.01$ compared with the WT by Student's $t$-test. 


\section{Discussion}

In past decades, several genes involved in regulating crown root growth and development have been identified and characterized in rice, including CRL4/GNOM1, CRL5, SRT5, and WOX11 [2,25,29-31]. However, the molecular mechanisms of rice crown root development are still unclear. In this study, we isolated a new mutant scr8 from indica R1206 involved in temperature response and hormone synthesis that affected the crown root growth and development.

Root growth depends on cell proliferation and elongation, in which the former mainly occurs in the RAM, and root length is affected when meristem zone activity decreases, such as GR2, DPR2, and CBLs in plants [31-37]. In this study, the scr8 mutant showed shorter primary roots and crown roots, decreased root meristem activity, and reduced meristem length (Figure $2 \mathrm{~F}, \mathrm{G}$ ). In addition, the expression levels of cell-cycle-related genes $C D C 2$, CYCA1;3, CYCA2;1, CYCD4;2, and E2F2 were downregulated in $s c r 8$ grown at $32{ }^{\circ} \mathrm{C}$ but significantly upregulated when grown at $20^{\circ} \mathrm{C}$ (Figure 9A,B). Moreover, the RNA-seq data also exhibited significant changes in the expression of cell-cycle-related genes at different temperatures. These results indicate that cell division and elongation were inhibited and meristem activity was reduced in $s c r 8$, which led to the defect of crown root development in scr8.
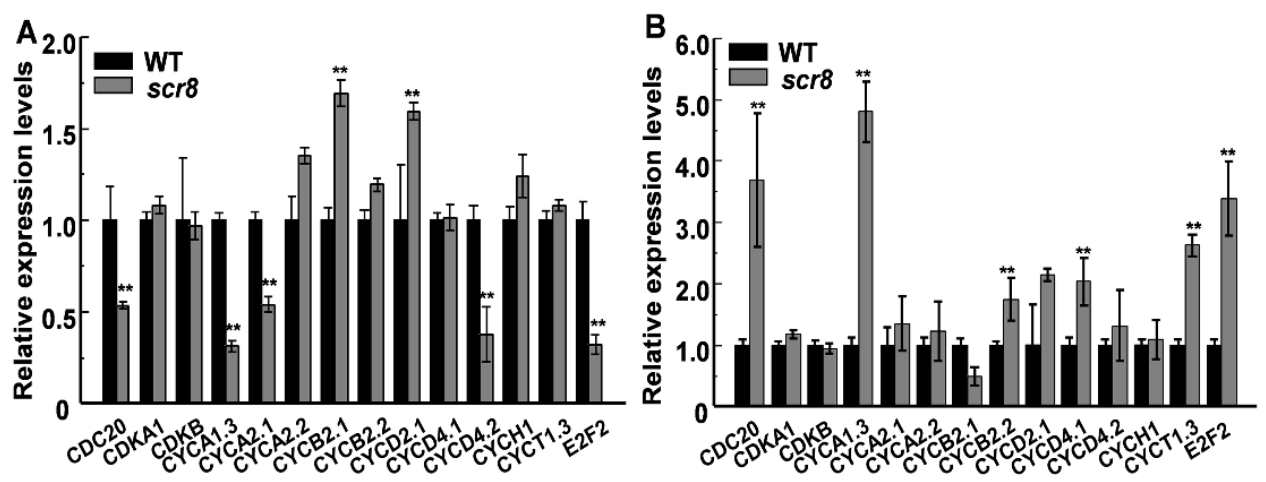

Figure 9. Expression analysis of genes related to cell cycle in WT and scr8. (A) Genes expression of WT and scr 8 grown at $32{ }^{\circ} \mathrm{C}$. (B) Genes expression of WT and scr 8 grown at $20{ }^{\circ} \mathrm{C}$. Error bars represent SD. ${ }^{*}$ Significant difference at $p<0.01$ compared with the WT by Student's $t$-test.

In the long-term evolutionary process, plants have established complex and diverse resistance response systems to resist the invasion of pathogens and insects. However, the abnormality of plant defense response disturbs the balance between plant growth and resistance response, resulting in a variety of abnormal phenotypes, such as lesion mimic leaf, spotted leaf, shorter root, hybrid weakness, and so on [15,38-43]. Therefore, plants must coordinate the balance between immune response and growth in a constantly changing environment. The previous studies have shown that the proteins containing NBARC and LRR domains play key roles in the maintenance of the autoinhibited state, and the mutations of these domains activates plant defense responses [38-41]. NRTP1 encodes a typical coiled-coil nucleotide-binding leucine-rich repeat (CC-NB-LRR)-type protein, and its semi-dominant mutant showed defense response characteristics and exhibited shorter roots [39]. Hwi1 comprises two loci-25L1 and 25L2-and both encode leucine-rich repeat receptor-like kinase (LRR-RLK), which is incompatible with Hwi2 derived from wild rice (Oryza rufipogon). The hybrid weakness caused by the pyramiding of Hwi1 and Hwi2 activates an autoimmune response in the basal nodes of hybrids, interrupts root formation, and impairs shoot growth. [14]. Similarly, the candidate gene LOC_Os08g14850 encodes a CC-NBS-LRR-type protein containing NB-ARC domain (Figure 6A-D). In addition, the expression of PR genes were significantly increased, and the inoculation experiment also showed that the resistance to pathogens was enhanced in scr8 (Figure 8A,B,E). Thus, the 
interaction between the NB-ARC domain and LRR domain may be disrupted in scr8, resulting in auto-activation of the defense response.

It is well known that ambient temperature significantly affects plant growth and development [15,44-46]. R or R-like proteins of NB-LRR type play a receptor-like function and participate in specific recognition of pathogens, which are likely the causal temperaturesensitive component in defense responses [41]. High temperature usually decreases plant resistance, but it occasionally activates resistance [15,41,47-51]. In this study, the scr8 showed dwarf, short root phenotype, and the resistance to Xoo was enhanced more than wildtype under high temperature in filed. However, the $s c r 8$ phenotype of crown root growth defect was rescued by low-temperature treatment (Figure $4 \mathrm{~A}-\mathrm{D}$ ), and the expression of LOC_Os08g14850 was significantly higher than $\mathrm{WT}$ at $32{ }^{\circ} \mathrm{C}$, but there was no change at $20^{\circ} \mathrm{C}$ (Figure 6E). Therefore, the $s c r 8$ may respond to high temperature signals and abnormally initiate defense responses.

The reported crown root growth defect materials are usually related to plant hormone synthesis and metabolism disorders [2,6,52-54]. SA and JA are two well-known phytohormones involved in plant defense responses. Among them, SA plays an important role in maintaining the root meristem activity, and the decrease in SA content leads to a reduction in root meristem activity [6,55]. JA acts on the stem cells and tissue regeneration, and negatively regulates the adventitious root formation [16,56-60]. In scr8, the SA and JA were highly accumulated in the leaves and roots (Figure $5 B, C$ ), and the resistance to bacteria pathogen Xoo was also strikingly increased in leaves (Figure 8A,B), suggesting that plant defense responses were activated. RNA-seq and expression levels analysis also demonstrated these results, and EdU staining indicated that the root meristem activity had decreased in $\operatorname{scr} 8$ (Figures 2F,G and 7). Thus, we speculated that $S C R 8$ is required for crown root development, and its mutation may result in the accumulations of SA and JA and induce plant defense response.

The scr 8 exhibits an abnormal crown root development under high temperature, which is involved in plant defense response. However, the regulating mechanism of plant defense response under high temperature and whether the mechanism in root is the same as that of shoot are not known. Therefore, identification of novel genetic loci that regulate crown root development and characterization of corresponding regulatory genes would extend our understanding of rice root development. Here, we reported SCR8 gene as a new genetic locus controlling crown root development, in which it will be helpful to further explore the balance between root growth and defense response under the changing environment.

\section{Materials and Methods}

\subsection{Plant Materials and Growth Conditions}

The rice (Oryza sativa) scr8 mutant was obtained from a natural variation of indica variety R1206 in the field. Genetic and phenotypic analyses were performed using the $\mathrm{F} 1$ and $\mathrm{F} 2$ generations of a cross between the $\mathrm{scr} 8$ mutant and a japonica rice cultivar, WuYunGeng7(WYG7). The WYG7, R1206, SCR8, and F2 population were grown in the field at Hangzhou, Zhejiang Province, China, and Lingshui, Hainan Province, China, under natural growth conditions.

Hydroponic experiments and histological analysis were conducted using Yoshida's culture solution [61]. Seeds were soaked in water at $37^{\circ} \mathrm{C}$ for 2 days, followed by germination for 1 day at $37^{\circ} \mathrm{C}$. The most uniformly germinated seeds were sown in a 96-well plate. Two days later, the seedlings were cultured in Yoshida's culture solution. All plants were grown in a chamber with a $12 \mathrm{~h}$ dark $/ 12 \mathrm{~h}$ light cycle at $60 \%$ humidity. For the temperature sensitivity experiment, plants were cultivated at $20^{\circ} \mathrm{C}, 24^{\circ} \mathrm{C}, 28^{\circ} \mathrm{C}$, and $32^{\circ} \mathrm{C}$ from germination to 2 weeks old. For the temperature shift experiment, plants were grown at $20^{\circ} \mathrm{C}$ or $32{ }^{\circ} \mathrm{C}$ to 7 days and then shifted to $32{ }^{\circ} \mathrm{C}$ or $20^{\circ} \mathrm{C}$. The root length was measured every day under the different temperature conditions [14]. 


\subsection{Phenotypical Characterization and Histological Analysis}

To investigate whether the $s c r 8$ mutation affects rice yield, plant height, panicle length, tiller number, and grain number were determined for each of 15 independent plants. Grain length, grain width, and 1000-grain weight were measured by a ScanMaker i800 (MICROTEK, China).

For paraffin sectioning, plant materials were fixed in 70\% FAA overnight, and section analysis was performed, as described previously [62]. All sections were observed under a light microscope.

\subsection{EdU Staining}

EdU staining was performed using an EdU kit (C0071L, BeyoClick EdU-488; Beyotime), according to the manufacturer's instructions and previous studies [6,27]. Plants at 3 days after germination (DAG) were immersed in $20 \mathrm{mM}$ EdU solution for $2 \mathrm{~h}$, fixed for $15 \mathrm{~min}$ in $4 \%$ paraformaldehyde in phosphate buffer $(140 \mathrm{mM} \mathrm{NaCl}, 2.7 \mathrm{mM} \mathrm{KCl}, 10 \mathrm{mM}$ Na2HPO4, $1.8 \mathrm{mM} \mathrm{KH} 2 \mathrm{PO} 4,0.1 \%$ Tritonx-100, $\mathrm{pH} 7.2$ ) at room temperature, and then in EdU detection cocktail. Root tips were observed under the GFP channel on a Carl Zeiss LSM 710 confocal microscope.

\subsection{Pathological Analysis}

Rice plants were inoculated with Xoo strains PXO99A and Zhe173 by the leaf-clipping method at the heading stage, and lesion length was scored 15 days after inoculation [63]. At least 10 individual plants and three tillers of each plant were inoculated with one strain.

\subsection{Determination of Free SA and JA by HPLC}

For SA and JA measurements, seedlings were grown in culture solution for 7 days. The leaves and roots were separately collected and stored at $-80{ }^{\circ} \mathrm{C}$. The different tissues were used for SA and JA measurements using a protocol reported previously. In short, $100 \mathrm{mg}$ sample were frozen in liquid nitrogen immediately and ground to a fine powder. Homogenates were extract in $1 \mathrm{~mL} 90 \%$ methanol water solution at $4{ }^{\circ} \mathrm{C}$ overnight. The samples were centrifuged at 10,000 g for $10 \mathrm{~min}$ and supernatants were transferred to a new tube. The precipitates were re-extracted with $0.5 \mathrm{~mL} \mathrm{90 \%} \mathrm{methanol} \mathrm{solution.} \mathrm{The} \mathrm{combined}$ supernatants were vacuum-dried and dissolved with $20 \mu \mathrm{L}$ trichloroacetic acid solution $(1 \mathrm{mg} / \mathrm{mL})$, mixed, and vibrated for $1 \mathrm{~min}$. The mixture was extracted with $1 \mathrm{~mL}$ ethyl acetate and cyclohexane solution (V/V 1:1), and the upper organic phase was transferred to a new EP tube, followed by drying under nitrogen and dissolution with $0.5 \mathrm{~mL}$ mobile phase for the HPLC [64].

\subsection{Map-Based Cloning}

To fine-map the mutated gene, scr 8 was crossed with WYG7, and 768 recessive individuals were generated from the F2 mapping population. For fine-gene mapping, new SSR, $\mathrm{SNP}$, or InDel molecular markers were developed. Gene prediction within the $126.4 \mathrm{~kb}$ fine-mapped region on chromosome 8 was performed using the publicly available rice database Rice Genome Annotation Project (RGAP, http:/ / rice.plantbiology.msu.edu accessed on 6 February 2013). Genomic DNA was extracted from the samples using the hexadecyltrimethylammonium bromide (CTAB) method [65]. The PCR mixture included $5 \mu \mathrm{L} 2 \times$ PCR mix (Yeasen), $1 \mu \mathrm{L}$ DNA template, $0.5 \mu \mathrm{L}$ each of forward and reverse primers $(10 \mu \mathrm{mol} / \mathrm{L})$, and $\mathrm{H} 2 \mathrm{O}$ to a final volume of $10 \mu \mathrm{L}$. The PCR amplification program was as follows: pre-denaturation at $94{ }^{\circ} \mathrm{C}$ for $4 \mathrm{~min}$; denaturation at $94{ }^{\circ} \mathrm{C}$ for $30 \mathrm{~s}$, annealing at $55-60{ }^{\circ} \mathrm{C}$ for $30 \mathrm{~s}$ (depending on the primers), extension at $72{ }^{\circ} \mathrm{C}$ for $30 \mathrm{~s} 40$ cycles, and a final extension at $72{ }^{\circ} \mathrm{C}$ for $10 \mathrm{~min}$. The PCR products were separated by electrophoresis on a $4 \%$ agarose gel, photographed, and the data stored in a gel imager for read. The primers used are listed in Table S1 in the Supplementary Materials. 


\subsection{RNA Extraction and qRT-PCR Analysis}

Total RNA was isolated with TRIzol reagent (Takara) from the roots and leaves of different plants, and cDNA was synthesized with ReverTra Ace kit (Toyobo) and then diluted for qRT-PCR using the SYBR Green PCR Master Mix kit (Applied Biosystems) in ABI7900 (Applied Biosystems). The reaction mixtures contained $2 \mu \mathrm{L}$ cDNA template, $10 \mu \mathrm{L} 2 \times$ SYBR qPCR mix, $0.8 \mu \mathrm{L}$ each of forward and reverse primers, and ddH2O to a final volume of $20 \mu \mathrm{L}$. The reaction program was $95^{\circ} \mathrm{C}$ for $30 \mathrm{~s}, 95^{\circ} \mathrm{C}$ for $5 \mathrm{~s}, 60{ }^{\circ} \mathrm{C}$ for $15 \mathrm{~s}$, and $72{ }^{\circ} \mathrm{C}$ for $30 \mathrm{~s}$ for 40 cycles. Each reaction was performed in triplicate. The cycle threshold $(\mathrm{Ct})$ method was used to calculate relative amounts of mRNA. Student's $t$-test was used to analyze the significance of differences. The rice OsActin (Os04g0177600) gene was used as the endogenous control, and three replicates were performed for all experiments. The primers used are listed in Table S1 in the Supplementary Materials.

\subsection{RNA-Seq and Data Analysis}

Plants were grown at $20^{\circ} \mathrm{C}$ and $28^{\circ} \mathrm{C}$, and the roots were harvested for total RNA extraction at the 7th day. Three biological replicates (each comprising roots from 10 individuals) were used for RNA-seq analysis. The RNA-seq libraries were constructed and sequenced using the Illumina HiSeq (Illumina company), and each sample obtained approximately 50,000,000 clean reads. The reads were mapped to Nipponbare reference genome according to the genome information (ensemble, IRGSP-1.0, INSDC Assembly, version 103.7) by Tophat. DEGs were identified by edgeR with FDR $<0.05$ and $\mid \log 2$ (fold change) | >1) [66]. GO enrichment analysis was implemented with agriGO (http:/ / bioinfo.cau.edu.cn/agriGO accessed on 31 May 2021).

Supplementary Materials: The following are available online at https:/ /www.mdpi.com/article/10 .3390/ijms22189868/s1.

Author Contributions: Project administration, J.H. and Y.R.; funding acquisition, J.H., G.Z. and Q.Q.; supervision, J.H.; writing - original draft preparation, P.H. and Y.W. (Yi Wen); investigation, P.H., H.W., K.W. and L.Z. (Lixin Zhu); data curation, P.H., Y.W. (Yi Wen), Y.W. (Yueying Wang), B.C. and J.W.; methodology, D.R., L.Z. (Li Zhu), Z.G., S.Y., J.X., G.Z., L.G. and D.Z. All authors have read and agreed to the published version of the manuscript.

Funding: This study was supported by the Natural Science Foundation of China (31861143006, 31871594), Zhejiang Province Outstanding Youth Fund (LR19C130001), Zhejiang Provincial “Ten Thousand Talent Program" Project (2018R52025), the National Natural Science Foundation of China (31901483), the Key Research and Development Program of Jiangxi Province, China (20181ACF60001).

Conflicts of Interest: The authors declare no conflict of interest.

\section{References}

1. Bellini, C.; Pacurar, D.I.; Perrone, I. Adventitious roots and lateral roots: Similarities and differences. Annu. Rev. Plant Biol. 2014, 65, 639-666. [CrossRef]

2. Zhao, Y.; Cheng, S.; Song, Y.; Huang, Y.; Zhou, S.; Liu, X.; Zhou, D.X. The interaction between rice ERF3 and WOX11 promotes crown root development by regulating gene expression involved in cytokinin signaling. Plant Cell 2015, 27, 2469-2483. [CrossRef]

3. Wang, X.F.; He, F.F.; Ma, X.X.; Mao, C.Z.; Hodgman, C.; Lu, C.G.; Wu, P. OsCAND1 is required for crown root emergence in rice. Mol. Plant 2011, 4, 289-299. [CrossRef]

4. Perilli, S.; Di-Mambro, R.; Sabatini, S. Growth and development of the root apical meristem. Curr. Opin. Plant Biol. 2012, 15, 17-23. [CrossRef]

5. Zhai, H.; Zhang, X.; You, Y.; Lin, L.; Zhou, W.; Li, C. SEUSS integrates transcriptional and epigenetic control of root stem cell organizer specification. EMBO J. 2020, 39, e105047. [CrossRef]

6. Xu, L.; Zhao, H.Y.; Ruan, W.Y.; Deng, M.J.; Wang, F.; Peng, J.R.; Luo, J.; Chen, Z.X.; Yi, K.K. ABNORMAL INFLORESCENCE MERISTEM1 functions in salicylic acid biosynthesis to maintain proper reactive oxygen species levels for root meristem activity in rice. Plant Cell 2017, 29, 560-574. [CrossRef]

7. Zhou, S.; Jiang, W.; Long, F.; Cheng, S.; Yang, W.; Zhao, Y.; Zhou, D.X. Rice homeodomain protein WOX11 recruits a histone acetyltransferase complex to establish programs of cell proliferation of crown root meristem. Plant Cell 2017, 29, 1088-1104. [CrossRef] 
8. Shao, Y.M.; Yu, X.X.; Xu, X.W.; Li, Y.; Yuan, W.X.; Xu, Y.; Mao, C.Z.; Zhang, S.Q.; Xu, J. The YDA-MKK4/MKK5-MPK3/MPK6 cascade functions downstream of the rgf1-rgi ligand-receptor pair in regulating mitotic activity in root apical meristem. Mol. Plant 2020, 13, 1608-1623. [CrossRef]

9. Lu, X.T.; Shi, H.Y.; Ou, Y.; Cui, Y.W.; Chang, J.K.; Peng, L.; Gou, X.P.; He, K.; Li, J. RGF1-RGI1, a peptide-receptor complex, regulates Arabidopsis root meristem development via a MAPK signaling cascade. Mol. Plant 2020, 2, 1594-1607. [CrossRef]

10. Shao, Y.L.; Zhou, H.Z.; Wu, Y.R.; Zhang, H.; Lin, J.; Jiang, X.Y.; He, Q.J.; Zhu, J.S.; Li, Y.; Yu, H.; et al. OsSPL3, an SBP-domain protein, regulates crown root development in rice. Plant Cell 2019, 31, 1257-1275. [CrossRef]

11. Zhu, J.S.; Li, Y.; Lin, J.; Wu, Y.R.; Guo, H.X.; Shao, Y.L.; Wang, F.; Wang, X.F.; Mo, X.R.; Zheng, S.J.; et al. CRD1, an XPO1 domain protein, regulates mirna accumulation and crown root development in rice. Plant J. 2019, 100, 328-342. [CrossRef]

12. Martins, S.; Montiel-Jorda, A.; Cayrel, A.; Huguet, S.; Roux, C.P.; Ljung, K.; Vert, G. Brassinosteroid signaling-dependent root responses to prolonged elevated ambient temperature. Nat. Commun. 2017, 8, 309. [CrossRef]

13. Chen, K.; Guo, T.; Li, M.X.; Zhang, Y.M.; Yang, Y.B.; Ye, W.W.; Dong, N.Q.; Shi, C.L.; Kan, Y.; Xiang, Y.H.; et al. Translational regulation of plant response to high temperature by a dual function trnahis guanylyltransferase in rice. Mol. Plant 2019, 12, 1123-1142. [CrossRef]

14. Chen, C.; Chen, H.; Lin, Y.S.; Shen, J.B.; Shan, J.X.; Qi, P.; Shi, M.; Zhu, M.Z.; Huang, X.H.; Feng, Q.; et al. A two-locus interaction causes interspecific hybrid weakness in rice. Nat. Commun. 2014, 5, 3357. [CrossRef]

15. Petricka, J.J.; Winter, C.M.; Benfey, P.N. Control of Arabidopsis root development. Annu. Rev. Plant Biol. 2012, 63, 563-590. [CrossRef]

16. Gutierrez, L.; Mongelard, G.; Flokova, K.; Pacurar, D.I.; Novak, O.; Staswick, P.; Kowalczyk, M.; Pacurar, M.; Demailly, H.; Geiss, G.; et al. Auxin controls Arabidopsis adventitious root initiation by regulating jasmonic acid homeostasis. Plant Cell 2012, 24, 2515-2527. [CrossRef]

17. Olatunji, D.; Geelen, D.; Verstraeten, I. Control of endogenous auxin levels in plant root development. Int. J. Mol. Sci. 2017, 18, 2587. [CrossRef] [PubMed]

18. Xun, Q.; Wu, Y.; Li, H.; Chang, J.; Ou, Y.; He, K.; Gou, X.; Tax, F.E.; Li, J. Two receptor-like protein kinases, MUSTACHES and MUSTACHES-LIKE, regulate lateral root development in Arabidopsis thaliana. New Phytol. 2020, 227, 1157-1173. [CrossRef] [PubMed]

19. Wu, Y.; Xun, Q.; Guo, Y.; Zhang, J.; Cheng, K.; Shi, T.; He, K.; Hou, S.; Gou, X.; Li, J. Genome-wide expression pattern analyses of the Arabidopsis leucine-rich repeat receptor-like kinases. Mol. Plant 2016, 9, 289-300. [CrossRef]

20. Goh, T.; Joi, S.; Mimura, T.; Fukaki, H. The establishment of asymmetry in Arabidopsis lateral root founder cells is regulated by LBD16/ASL18 and related LBD/ASL proteins. Development 2012, 139, 883-893. [CrossRef] [PubMed]

21. Zhang, F.; Tao, W.; Sun, R.; Wang, J.; Li, C.; Kong, X.; Tian, H.; Ding, Z. PRH1 mediates ARF7-LBD dependent auxin signaling to regulate lateral root development in Arabidopsis thaliana. PLoS Genet. 2020, 16, e1008044. [CrossRef]

22. Coudert, Y.; Le, V.A.; Adam, H.; Bes, M.; Vignols, F.; Jouannic, S.; Guiderdoni, E.; Gantet, P. Identification of CROWN ROOTLESS1regulated genes in rice reveals specific and conserved elements of postembryonic root formation. New Phytol. 2015, 206, 243-254. [CrossRef]

23. Liu, H.; Wang, S.; Yu, X.; Yu, J.; He, X.; Zhang, S.; Shou, H.; Wu, P. ARL1, a LOB-domain protein required for adventitious root formation in rice. Plant J. 2005, 43, 47-56. [CrossRef]

24. Inukai, Y.; Sakamoto, T.; Ueguchi-Tanaka, M.; Yohko, S.; Kenji, G.; Iichiro, U.; Yasuko, H.; Motoyuki, A.; Hidemi, K.; Makoto, M. Crown rootless1, which is essential for crown root formation in rice, is a target of an auxin response factor in auxin signaling. Plant Cell 2005, 17, 1387-1396. [CrossRef] [PubMed]

25. Zhao, Y.; Hu, Y.; Dai, M.; Huang, L.; Zhou, D.X. The wuschel-related homeobox gene WOX11 is required to activate shoot-borne crown root development in rice. Plant Cell 2009, 21, 736-748. [CrossRef] [PubMed]

26. Gao, S.; Fang, J.; Xu, F.; Wang, W.; Sun, X.; Chu, J.; Cai, B.; Feng, Y.; Chu, C. Cytokinin oxidase/dehydrogenase4 integrates cytokinin and auxin signaling to control rice crown root formation. Plant Physiol. 2014, 165, 1035-1046. [CrossRef] [PubMed]

27. Lin, Q.; Zhang, Z.; Wu, F.; Feng, M.; Sun, Y.; Chen, W.W.; Cheng, Z.; Zhang, X.; Ren, Y.; Lei, C.; et al. The APC/CTE E3 ubiquitin ligase complex mediates the antagonistic regulation of root growth and tillering by aba and ga. Plant Cell 2020, 32, $1973-1987$. [CrossRef]

28. Zhou, W.; Lozano-Torres, J.L.; Blilou, I.; Zhang, X.; Zhai, Q.; Smant, G.; Li, C.; Scheres, B. A jasmonate signaling network activates root stem cells and promotes regeneration. Cell 2019, 177, 942-956. [CrossRef] [PubMed]

29. Chen, Q.; Sun, J.; Zhai, Q.; Zhou, W.; Qi, L.; Xu, L.; Wang, B.; Chen, R.; Jiang, H.; Qi, J.; et al. The basic helix-loop-helix transcription factor MYC2 directly represses PLETHORA expression during jasmonate-mediated modulation of the root stem cell niche in Arabidopsis. Plant Cell 2011, 23, 3335-3352. [CrossRef]

30. Liu, S.; Wang, J.; Wang, L.; Wang, X.; Xue, Y.; Wu, P.; Shou, H. Adventitious root formation in rice requires OsGNOM1 and is mediated by the OsPINs family. Cell Res. 2009, 19, 1110-1119. [CrossRef]

31. Kitomi, Y.; Ito, H.; Hobo, T.; Aya, K.; Kitano, H.; Inukai, Y. The auxin responsive AP2/ERF transcription factor CROWN ROOTLESS5 is involved in crown root initiation in rice through the induction of OsRR1, a type-A response regulator of cytokinin signaling. Plant J. 2011, 67, 472-484. [CrossRef]

32. Takatsuka, H.; Umeda, M. Hormonal control of cell division and elongation along differentiation trajectories in roots. J. Exp. Bot. 2014, 65, 2633-2643. [CrossRef] 
33. Pavelescu, I.; Vilarrasa-Blasi, J.; Planas-Riverola, A.; Gonzalez-Garcia, M.P.; Cano-Delgado, A.I.; Ibanes, M. A sizer model for cell differentiation in Arabidopsis thaliana root growth. Mol. Syst. Biol. 2018, 14, e7687. [CrossRef]

34. Yu, P.; Gutjahr, C.; Li, C.; Hochholdinger, F. Genetic control of lateral root formation in cereals. Trends Plant Sci. 2016, 21, 951-961. [CrossRef] [PubMed]

35. Yu, X.; Pasternak, T.; Eiblmeier, M.; Ditengou, F.; Kochersperger, P.; Sun, J.; Wang, H.; Rennenberg, H.; Teale, W.; Paponov, I.; et al. Plastid-localized Glutathione Reductase2-Regulated glutathione redox status is essential for Arabidopsis root apical meristem maintenance. Plant Cell 2013, 25, 4451-4468. [CrossRef] [PubMed]

36. Zou, Y.; Zhang, X.; Tan, Y.; Huang, J.B.; Zheng, Z.; Tao, L.Z. Phosphoethanolamine N-methyltransferase 1 contributes to maintenance of root apical meristem by affecting ROS and auxin-regulated cell differentiation in Arabidopsis. New Phytol. 2019, 224, 258-273. [CrossRef] [PubMed]

37. Liu, G.; Yang, W.; Zhang, X.; Peng, T.; Zou, Y.; Zhang, T.; Wang, H.; Liu, X.; Tao, L. Cystathionine beta-lyase is crucial for embryo patterning and the maintenance of root stem cell niche in Arabidopsis. Plant J. 2019, 99, 536-555. [CrossRef]

38. Tang, J.Y.; Zhu, X.D.; Wang, Y.Q.; Liu, L.C.; Xu, B.; Li, F.; Fang, J.; Chu, C.C. Semi-dominant mutations in the CC-NB-LRR-TYPE R gene, NLS1, lead to constitutive activation of defense responses in rice. Plant J. 2011, 66, 996-1007. [CrossRef] [PubMed]

39. Yu, Z.; Dong, L.; Jiang, Z.; Yi, K.; Zhang, J.; Zhang, Z.; Zhu, Z.; Wu, Y.; Xu, M.; Ni, J. A semi-dominant mutation in a CC-NB-LRRtype protein leads to a short-root phenotype in rice. Rice 2018, 11, 54. [CrossRef]

40. Takken, F.L.; Goverse, A. How to build a pathogen detector: Structural basis of NB-LRR function. Curr. Opin. Plant Biol. 2012, 15, 375-384. [CrossRef]

41. Zhu, Y.; Qian, W.; Hua, J. Temperature modulates plant defense responses through NB-LRR proteins. PLoS Pathog. 2010, 6, e1000844. [CrossRef] [PubMed]

42. Liu, Q.E.; Ning, Y.S.; Zhang, Y.X.; Yu, N.; Zhao, C.D.; Zhan, X.D.; Wu, W.X.; Chen, D.B.; Wei, X.J.; Wang, G.L.; et al. OsCUL3a negatively regulates cell death and immunity by degrading OsNPR1 in rice. Plant Cell 2017, 29, 345-359. [CrossRef] [PubMed]

43. Rao, Y.C.; Jiao, R.; Wang, S.; Wu, X.M.; Ye, H.F.; Pan, C.Y.; Li, S.F.; Xin, D.D.; Zhou, W.Y.; Dai, G.X.; et al. SPL36 encodes a receptor-like protein kinase that regulates programmed cell death and defense responses in rice. Rice 2021, 14, 34.

44. Wigge, P.A. Ambient temperature signalling in plants. Curr. Opin. Plant Biol. 2013, 16, 661-666. [CrossRef]

45. Jeuken, M.J.; Zhang, N.W.; McHale, L.K.; Pelgrom, K.; Boer, D.E.; Lindhout, P.; Michelmore, R.W.; Visser, R.G.; Niks, R.E. Rin4 causes hybrid necrosis and race-specific resistance in an interspecific lettuce hybrid. Plant Cell 2009, 21, 3368-3378. [CrossRef] [PubMed]

46. Franklin, K.A.; Lee, S.H.; Patel, D.; Kumar, S.V.; Spartz, A.K.; Gu, C.; Ye, S.; Yu, P.; Breen, G.; Cohen, J.D.; et al. Phytochromeinteracting factor 4 (PIF4) regulates auxin biosynthesis at high temperature. Proc. Natl. Acad. Sci. USA 2011, 108, 20231-20235. [CrossRef]

47. Garrett, K.A.; Dendy, S.P.; Frank, E.E.; Rouse, M.N.; Travers, S.E. Climate change effects on plant disease: Genomes to ecosystems. Annu. Rev. Phytopathol. 2006, 44, 489-509. [CrossRef]

48. Yoneya, Y.; Wakabayashi, T.; Kato, K. The temperature sensitive hybrid breakdown 1 induces low temperature-dependent intrasubspecific hybrid breakdown in rice. Breed. Sci. 2021, 71, 268-276. [CrossRef]

49. Fu, D.; Uauy, C.; Distelfeld, A.; Blechl, A.; Epstein, L.; Chen, X.; Sela, H.; Fahima, T.; Dubcovsky, J. A Kinase-START gene confers temperature-dependent resistance to wheat stripe rust. Science 2009, 323, 1357-1360. [CrossRef]

50. Cheng, C.; Gao, X.Q.; Feng, B.M.; Sheen, J.; Shan, L.B.; He, P. Plant immune response to pathogens differs with changing temperatures. Nat. Commun. 2013, 4, 2530. [CrossRef]

51. Webb, K.M.; Ona, I.; Bai, J.; Garrett, K.; Mew, T.; Vera-Cruz, C.M.; Leach, J.E. A benefit of high temperature: Increased effectiveness of a rice bacterial blight disease resistance gene. New Phytol. 2010, 185, 568-576. [CrossRef] [PubMed]

52. Zhu, Z.X.; Liu, Y.; Liu, S.J.; Mao, C.Z.; Wu, Y.R.; Wu, P. A gain-of-function mutation in OsIAA11 affects lateral root development in rice. Mol. Plant 2012, 5, 154-161. [CrossRef]

53. Behrens, I.V.; Komatsu, M.; Zhang, Y.X.; Berendzen, K.W.; Niu, X.M.; Sakai, H.; Taramino, G.; Hochholdinger, F. Rootless with undetectable meristem 1 encodes a monocot-specific AUX/IAA protein that controls embryonic seminal and post-embryonic lateral root initiation in maize. Plant J. 2011, 66, 341-353. [CrossRef]

54. Zheng, H.; Li, S.; Ren, B.; Zhang, J.; Ichii, M.; Taketa, S.; Tao, Y.; Zuo, J.; Wang, H. LATERAL ROOTLESS2, a cyclophilin protein, regulates lateral root initiation and auxin signaling pathway in rice. Mol. Plant 2013, 6, 1719-1721. [CrossRef]

55. Kusumi, K.; Yaeno, T.; Kojo, K.; Hirayama, M.; Hirokawa, D.; Yara, A.; Iba, K. The role of salicylic acid in the glutathione-mediated protection against photooxidative stress in rice. Physiol Plant 2006, 128, 651-661. [CrossRef]

56. Raya-Gonzalez, J.; Pelagio-Flores, R.; Lopez-Bucio, J. The jasmonate receptor COI1 plays a role in jasmonate-induced lateral root formation and lateral root positioning in Arabidopsis thaliana. J. Plant Physiol. 2012, 169, 1348-1358. [CrossRef] [PubMed]

57. Xu, P.; Zhao, P.X.; Cai, X.T.; Mao, J.L.; Miao, Z.Q.; Xiang, C.B. Integration of jasmonic acid and ethylene into auxin signaling in root development. Front. Plant Sci. 2020, 11, 271. [CrossRef] [PubMed]

58. Cai, X.T.; Xu, P.; Zhao, P.X.; Liu, R.; Yu, L.H.; Xiang, C.B. Arabidopsis ERF109 mediates cross-talk between jasmonic acid and auxin biosynthesis during lateral root formation. Nat. Commun. 2014, 5, 5833. [CrossRef] [PubMed]

59. Ye, B.B.; Shang, G.D.; Pan, Y.; Xu, Z.G.; Zhou, C.M.; Mao, Y.B.; Bao, N.; Sun, L.; Xu, T.; Wang, J.W. AP2/ERF transcription factors integrate age and wound signals for root regeneration. Plant Cell 2019, 32, 226-241. [CrossRef] 
60. Zhang, G.; Zhao, F.; Chen, L.; Pan, Y.; Sun, L.; Bao, N.; Zhang, T.; Cui, C.X.; Qiu, Z.; Zhang, Y.; et al. Jasmonate-mediated wound signalling promotes plant regeneration. Nat. Plants 2019, 5, 491-497. [CrossRef]

61. Yoshida, S.; Forno, D.A.; Cock, J.H.; Gomez, K.A. Laboratory Manual for Physiological Studies of Rice; International Rice Research Institute: Los Banos, PH, USA, 1971; p. 61.

62. Ren, D.Y.; Rao, Y.C.; Huang, L.C.; Leng, Y.J.; Hu, J.; Lu, M.; Zhang, G.H.; Zhu, L.; Gao, Z.Y.; Dong, G.J.; et al. Fine mapping identifies a new QTL for brown rice rate in rice (oryza sativa l.). Rice 2016, 9, 4. [CrossRef] [PubMed]

63. Ruan, B.P.; Hua, Z.H.; Zhao, J.; Zhang, B.; Ren, D.Y.; Liu, C.L.; Yang, S.L.; Zhang, A.P.; Jiang, H.Z.; Yu, H.P.; et al. OsACL-A2 negatively regulates cell death and disease resistance in rice. Plant Biotechnol. J. 2019, 17, 1344-1356. [CrossRef]

64. Zheng, X.Y.; Zhou, M.; Yoo, H.; Pruneda-Paz, J.L.; Spivey, N.W.; Kay, S.A.; Dong, X. N Spatial and temporal regulation of biosynthesis of the plant immune signal salicylic acid. Proc. Natl. Acad. Sci. USA 2015, 112, 9166-9173. [CrossRef] [PubMed]

65. Murray, M.G.; Thompson, W.F. Rapid isolation of high molecular weight plant DNA. Nucleic Acids Res. 1980, 8, 4321-4325. [CrossRef]

66. Robinson, M.D.; McCarthy, D.J.; Smyth, G.K. Edger: A bioconductor package for differential expression analysis of digital gene expression data. Bioinformatics 2010, 26, 139-140. [CrossRef] [PubMed] 